\title{
EFFECTS OF LAND OWNERSHIP ON PSYCHOLOGICAL WELL-BEING OF THE POOR FARMERS OF THE NORTHERN PARTS OF BANGLADESH
}

\author{
Md. Mozibul Huq Azad Khan*, Md. Sarwar Jahan and Md. Ariful Haque
}

Department of Psychology, Rajshahi University, Rajshahi 6205, Bangladesh

\begin{abstract}
This study was designed to compare the psychological well-being of three categories of farmers in Bangladesh. They are the landless, Khas land allotees and the share-croppers. Charghat and Puthia Upazilla of Rajshahi District was the study area. Randomly selected 90 (30 from each group) respondents were the subjects of this study. To measure the psychological wellbeing the Bangla version of the MUNSH scale for Measuring happiness (Kazma and Stones 1980) was administered on the subjects. Results revealed that the psychological well-being of the Khas land allotees was best and psychological well-being of the landless was worst. On the other hand, the psychological well-being of the share-croppers was in between of the Khas land allotees and landless farmers.
\end{abstract}

Key words: Psychological well-being, rural poor, landless, owner of the Khas land

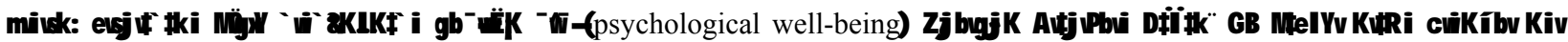

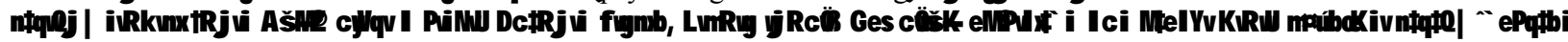

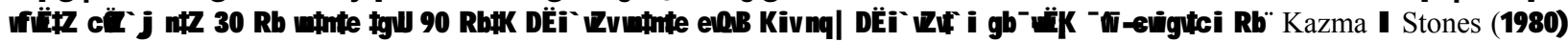

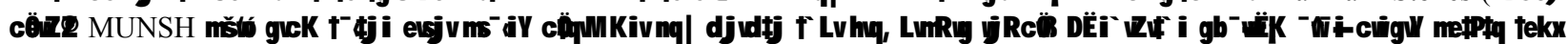

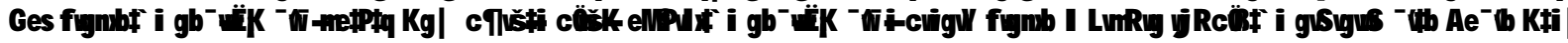

\section{Introduction}

Bangladesh is a densely populated developing country of the world with 834 people in per square kilometer. Total population is approximately 129 million (BBS 2000). Among them 28.8 million which is 23.39 percent live in urban areas and the remaining 94.3 million, which is 76.61 percent live in rural areas. Recent estimates show that nearly 78 percent of the population falls below the poverty line. A vast majority of this poverty stricken population (about 46.3 million) lives in the rural areas and about 5.5 percent of the rural households are landless in 1995/96s (SPB 1997).). Therefore, it is easily understood that a huge number of rural people are so poor who are not capable to fulfill their basic needs.

Ownership or possession of land, especially the agricultural land, is an important factor in the life of the rural people in Bangladesh. The history of land distribution indicates that all people did not have equal opportunity to own personal lands. Thus, some people become landowners and some others landless. Many of the landowners cannot cultivate by themselves. The landless peoples or the poor farmers cultivate these lands with an understanding of sharing the crops. On the other hand, 3.3 million acres of land was identified as Khas (government-owned) lands in Bangladesh (Barkat et al. 2001). It is assumed that yet there are some unidentified Khas lands in the country. Only a small portion of the identified Khas lands has so far been distributed to the poor farmers. The remaining of the *Corresponding author:kazad_psy@,ru.ac.bd huge Khas lands are illegally occupied by the rich and politically empowered segment of the society.

There are many survey reports on different aspects of agricultural lands, ownership of lands, distribution of wealth (Islam 1978), crop-sharing patterns (Hossain 1996), etc. Many reports include findings related to the life of the farmers who cultivate the agricultural lands. Studies were done to find out their physical and economic conditions (Barkat 1997). But nothing was done to study their mental health conditions as well as their psychological well-being. But it is needless to say that the mental health or psychological well-being of an individual is the key indicator of national development.

It is obvious that the mental health depends on physical health. Again many physical conditions depend on mental health. It was mentioned earlier that a large majority of the rural people are poor and are not capable to fulfill their basic needs. It is needless to point out that poverty play many adverse effects on the health of the farmers. Health is a state of complete physical, social and psychological well-being and not merely the absence of disease or infirmity. Review of literature revealed that the effects of poverty on psychological well-being and mental health of the farmers in Bangladesh was not well studied. Therefore, the present study was designed to study the effects of poverty on mental health of the rural poor farmers. Poor rural farmers of Bangladesh can be categorized in groups. In the present study they were categorized in the following three groups. 
Landless: People having zero land (cultivable land or house or any kind of land) are called Landless. Most of them take shelter by riverside dam, roadside, railway station or any open place. They don't cultivate any land as share-cropper. They always want to have a piece of land. Approximately 1,814,571 households in Bangladesh were totally 'landless' in 1990s (BBS 2000).

Khas land allotees: Some people who had no land of their own were allotted Khas lands for long time by the government. Normally a few decimal lands have been allotted for each landless household. Farmers of this category cultivate their allotted land and enjoy all the crops they cultivate.

Share-cropper: Actually they are destitute farmers. Most of them have no land of their own and cultivate the land of others with the agreement of sharing crops. But some of them have a little land for living.

It was mentioned earlier that the majority of the total population is living in the rural areas in Bangladesh and the main source of their livelihood and earning is agriculture. But it is the irony of fate that a huge number of this population is not fortunate enough to cultivate their own lands. They cultivate the lands of others. Even a large number of people do not possess their own land for habitation. At the same time, there is 3.3 million acres government owned land called Khas land which is almost unused or not properly used. If these Khas land can be distributed to the landless people, the fate of those people and their standard of living could be raised to a certain extent. In psychological research, it has been found that the mental health and psychological wellbeing of a person is directly correlated with the wealth he possesses and his ownership to that wealth (Easterlin 1974). Therefore, in the present study, the researchers primarily intended to measure and compare the mental health of the poor farmers in relation to their possession or ownership of lands of different kinds. In this regard, the researchers hypothesized that- psychological wellbeing of the rural poor farmers varies in degrees in relation to ownership or possession of lands.

\section{Methods}

Respondents: A total of ninety respondents of three different categories of rural poor farmers (i.e. landless, Khas land allotees and share-croppers) of Charghat and Puthia Upazilla of Rajshahi District were randomly selected in the study. Each of these groups consists of thirty respondents and they were selected from the different villages of those Upazilla. The local land office and the Chairman of the concerned Union Council (local government units) confirmed the land ownership status of the respondents as landless, Khas land allotees and share-croppers. The land utilization and crop cultivation pattern, irrigation facilities, etc, of these villages were similar. It was also observed that the NGO activities, Government support programs and development activities of the Union Council were similar in all those villages.

Instrument: The Bangla version as adapted by Akter (2003) of MUNSH scale for measuring happiness developed by Kazma and Stones, (1980) was used to measure the psychological well-being of the respondents. The original scale was a self-appraisal measure of happiness (well-being) among elderly. Items of the MUNSH scale were chosen on the basis of their correlation with avowed/ affirmed happiness and were intended to overcome the shortcomings in Bradburn's Affect Scale. More than seventy items from the BABS and other scales were included in the initial pool of items, from which twenty-four items were selected after cross validation. The final form of MUNSH contained five positive affect (PA) items, five negative affect (NA) items, seven items of positive experience (PE), and seven items of negative experience (NE).

Scores range potentially from 0 (lowest happiness) to 48 (highest happiness). The item analysis phase of the scale was conducted with a random sample of 301 adults aged 65-95 equally drawn from lists of elderly people living in urban, in rural and in institutional settings in Newfoundland. The results were cross- validated with a similar sample of 297 Newfoundland residents.

Scoring: The procedure used for MUNSH scale was to allow three choices of response for each item: Yes, Don't know and No. The responses were converted into the scores by a uniform scoring system. All responses were scored as follows:

Yes: 2; Don't know: 1; and No: 0. The total score was computed using the following formula: Total score $=$ PA - NA + PE - NE. Coefficient $\alpha$ values above 0.85 was reported for both samples for overall MUNSH scale. A test-retest correlation 0.70 was reported for 23 respondents interviewed 6-12 months after the initial interview. The Scale's items were initially "validated" in terms of their higher correlation (at the 0.005 significance level) with stated happiness. The overall MUNSH Scale correlated 0.67 with avowed happiness, compared to $0.50,0.55$ and 0.49 for three alternative scales of well-being and showed much internal consistency indicating discriminate validity as well. 
Procedure: At first the second author randomly selected all the ninety respondents (thirty from each group) from different villages of Charghat and Puthia Upazilla in Rajshahi District. The researchers met the respondents in different situations (home, work field, union council office, etc.) and had informal talks with them in order to establish a good rapport. Then the purpose of visit was briefly explained to each of them and they were requested to fill up the Information Blank, which included some personal information. After completion of Information Blank, the Bangla version of the MUNSH Scale was given to the respondents. As it is a self-administering scale, no specific instruction was given to the literate respondents. The respondents went through the instruction given on the top of the scale and marked the right answer using tick $(\checkmark)$ marks in the answer sheet. For the illiterate respondents, the researcher read and explained the instructions given on the scale. Then the second author read each item of the scale and marked the answer in accordance with the opinion given by the respondents. All data were collected in individual sessions and each session took approximately 30 to $45 \mathrm{~min}$ for the literate and illiterate respondents respectively.

\section{Results and Discussion}

In order to investigate the effects of ownership of lands on psychological well-beings of the poor farmers (i.e. landless, Khas land allotees and share-croppers) one way ANOVA and Student's t-tests were employed. The results are presented in Tables 1 and 2, respectively.

Table 1. Analysis of variance of the different categories of the respondents

\begin{tabular}{|l|c|c|c|c|}
\hline $\begin{array}{l}\text { Source of } \\
\text { variance }\end{array}$ & $\begin{array}{l}\text { Sum of } \\
\text { squares }\end{array}$ & Df & Mean squares & F-value \\
\hline $\begin{array}{l}\text { Between } \\
\text { Groups }\end{array}$ & 418.21 & 2 & 209.11 & \\
$\begin{array}{l}\text { Within } \\
\text { Group }\end{array}$ & 8589.58 & 87 & 98.73 & $2.33^{*}$ \\
Total & 9007.79 & 89 & & \\
$* \mathrm{P}<0.05$
\end{tabular}

Table 2. A comparison between different categories of respondents on their psychological well-beings

\begin{tabular}{|c|c|c|c|c|c|}
\hline $\begin{array}{l}\text { Category of } \\
\text { respondents }\end{array}$ & $\mathrm{N}$ & Mean & $\begin{array}{l}\text { Standard } \\
\text { deviation }\end{array}$ & $\mathrm{Df}$ & t-values \\
\hline $\begin{array}{l}\text { Khas land } \\
\text { allotees }\end{array}$ & 30 & 7.06 & 11.80 & \multirow[t]{2}{*}{58} & \multirow[t]{2}{*}{$2.21 *$} \\
\hline Landless & 30 & 0.43 & 11.50 & & \\
\hline Share-cropper & 30 & 2.00 & 6.27 & \multirow[t]{2}{*}{58} & \multirow[t]{2}{*}{$2.09 *$} \\
\hline $\begin{array}{l}\text { Khas land } \\
\text { allotees }\end{array}$ & 30 & 7.06 & 11.80 & & \\
\hline Landless & 30 & 0.43 & 11.50 & \multirow[t]{2}{*}{58} & \multirow[t]{2}{*}{$0.66 \mathrm{~ns}$} \\
\hline Share-cropper & 30 & 2.00 & 6.27 & & \\
\hline
\end{tabular}

$* \mathrm{Ns}=$ not significant; $*=\mathrm{P}<0.05$
One-way ANOVA involving groups was statistically significant $(\mathrm{F}=2.33, \mathrm{df}=2 / 87, \mathrm{p}<0.05)$, suggesting that there exists difference between the poor farmers. Comparisons between different categories of respondents are shown in Table 2. The results reveal that the mean happiness scores of landless, Khas land allotees and share-croppers are 0.43,7.06 and 2.00, respectively. This indicates that Khas land allotees have expressed highest happiness followed by share-croppers and least by landless respondents. Mean comparisons shows that the Khas land allotees $(M=7.06)$ have expressed significantly more happiness $(\mathrm{t}=2.21, \mathrm{df}=58$, $\mathrm{p}<0.05)$ than the landless respondents $(\mathrm{M}=0.43)$. Again, Khas land allotees $(\mathrm{M}=7.06)$ have expressed significantly more feelings of happiness $(\mathrm{t}=2.09, \mathrm{df}=58$, $\mathrm{p}<0.05)$ than the share-croppers $(\mathrm{M}=2.00)$. However, no significant mean difference was found between the landless and share-croppers. These findings indicate that ownership of land is an important factor to account for happiness of the farmers in Bangladesh.

The objective of the study was to measure and compare the psychological well-being of different categories (i.e. landless, Khas land allotees, and share-croppers) of rural poor farmers of Bangladesh. It was found that, there are significant differences of psychological wellbeing of the three categories of respondents. It was found that the psychological well-being of the farmers who have obtained lease of government Khas lands on a long term basis is better than that of the two other groups (share-croppers and landless) farmers. On the other hand, in a comparison between the landless and share-croppers, no significant difference is found in their psychological well-being.

These findings indicate that among the respondents, the psychological well-being of the Khas land allotees is the best and psychological well-being of the landless is the worst. The psychological well-beings of the sharecroppers are in between of other two groups. Therefore, it can be concluded that getting the control over the Khas lands like the other land owners improve the psychological well-being of the concerned farmers.

It was mentioned earlier that only a tiny portions of Khas lands have been distributed to the landless farmers in Bangladesh and the remaining millions of acres of Khas lands and water-bodies are still undistributed. Therefore, it is strongly recommended that if the remaining all kinds of government Khas lands, waterbodies and all other kinds of unused government lands are leased on a long-term basis to the landless farmers, it will improve their overall welfare and they will be able to contribute significantly in the national development. 


\section{References}

Akter B. 2003. Employment status, age, education and economic status of the family as related to the subjective well-being of women in Bangladesh. An unpublished master's thesis. The University of Rajshahi, Bangladesh.

Barkat A. 1997. "Population Scenario of Bangladesh: Growth, Structure and Distribution" presented at Workshop on Reproductive Health and Child Health, National Institute of Preventive and Social Medicine: Dhaka.

Barkat A. et al 2001. Political Economy of Khas Land in Bangladesh. Association for Land Reform and Development, Dhaka, Bangladesh, 86-106.

BBS. 2000. Statistical Yearbook of Bangladesh - 2000, Bangladesh Bureau of Statistics, Dhaka.

Easterlin RA. 1974. Does economic growth improve the human lot? Some empirical evidence. In P.A. David \& M. W. Reder (Eds.), Nations and households in economic growth. New York:Academic Press. pp. 89- 125.
Hossain A. 1996. Adhiar: Case Study Ranisankail (in Bangla), Right of Share cropper: Case Study Ranisankail, in Ahmed, S. (ed), Dinajpur: Ittihas O Oitigjo (History and Tradition), Bangladesh Itihas Somity (Bangladesh History Association), Dhaka, Bangladesh.

Islam S. 1978. Land Systems and Social Problems Of Bangladesh (in Bangla). Centre for Social Studies: Dhaka University, Dhaka, in Barkat, A. et al (2001). Political Economy of Khas Land in Bangladesh. Association for Land Reform and Development, Dhaka, Bangladesh, 86-106.

Kazma A, Stones M. 1980. The measurement of happiness: Development of the Memorial University of Newfoundland Scale of Happiness (MUNSH). Journal of Gerontology, 35, 906-912.

SPB. 1997. Statistical Pocket book of Bangladesh - 1997, Bangladesh Bureau of Statistics, Dhaka, p 184. 